\title{
Usulan Perawatan Mesin Stitching Dengan Metode Reliability Centered Maintenance
}

\author{
Rizki Arga Kurniawan*, Heri Mujayin \\ Jurusan Teknik Industri, Fakultas Teknik, Universitas Muhammadiyah Malang \\ Jl. Raya Tlogomas No. 246, Malang, Jawa Timur 65144 \\ *Surel: rizkiarga45@gmail.com
}

\begin{abstract}
Based on industrial competition nowadays, production quality occurs to be the main concern of severals top companies. Method of machine maintenance is a way to incresing their production quality. Nowadays, several companies still using a corrective maintenance to maintain their machine, which is all of machine maintenance only be performed if the machine damaged. This thesis only focus to high frequency stitching machine. This thesis using Reability centered maintenance method to obtain optimum maintenance interval. This method gathers 7 step of data processing, starting from data selection, determinating restricions of the system, descripting the system and function of block diagram, and then FMEA (Failure Mode Effect Analysis) and LTA (Logic Tree Analysis). The result of this method is a correct maintenance action for critical components that included in condition directed and time directed categories. Qulitative analysis for Reliability Centered Maintenance method includes types indectification of maintenance, cause of damage and the occuring failure. Resul of the research contain several maintenance actions for critical components using condition directed method and critical component replace schedule using time directed method. From the suggested system maintenance simulation with RCM method, downtime can be decrease until $47,83 \%$.
\end{abstract}

Keywords : maintenance, Downtime, Realibility Centered Maintenance, corrective maintenance.

\section{Abstrak}

Semakin besar persaingan didunia industri membuat perusahaan diharuskan untuk lebih meningkatkan kualitas produksinya. Metode perawatan mesin merupakan salah satu cara untuk meningkatkan kualitas produksi. Saat ini perusahaan masih menggunakan perawatan mesin yang bersifat corrective maintenance dimana kegiatan perawatan mesin dilakukan apabila mesin mengalami kerusakan. Pada makalah ini berfokus pada mesin dengan frekuensi yang tinggi, yaitu pada mesin stitching. Metode penelitian yang digunakan adalah Reability Centered Maintenance untuk mendapatkan interval perawatan yang optimum. Metode ini merangkum 7 tahapan pengolahan data mulai dari seleksi sistem dan pengumpulan informasi, penentuan batasan sistem, deskripsi sistem dan blok diagram fungsi, penentuan kegagalan sistem, kemudian dilanjutkan ke analisis FMEA (Failure Mode Effect Analysis) dan LTA (Logic Tree Analysis). Hasil yang diperoleh berupa suatu tindakan perawatan yang tepat pada komponen-komponen kritis yang termasuk kedalam kategori Condition Directed dan Time Directed. Analisa kualitatif pada metode Reliability Centered Maintenance meliputi pengidentifikasi jenis perawatan, penyebab kerusakan dan efek kegagalan yang terjadi. Dari hasil penelitian, didapatkan beberapa tindakan perawatan yang harus dilakukan pada komponen kritis yang bersifat Condition Directed dan jadwal pergantian optimum komponen kritis yang bersifat Time Directed. Dari simulasi sistem perawatan usulan dengan metode RCM ini didapatkan potensi penurunan tingkat downtime sebesar 47,83\%.

Kata kunci : maintenance, total minimum downtime, realibility centered maintenance (RCM), corrective maintenance. 


\section{Pendahuluan}

Perkembangan dunia industri yang semakin pesat mengakibatkan peningkatan persaingan dalam dunia industri, sehingga perusahaan - perusahaan bersaing untuk meningkatkan kualitas dan jumlah produksi. Upaya suatu perusahaan dalam meningkatkan jumlah produksi yaitu dengan memperpanjang suatu pengoperasian fasilitas industri dan mengurangi pengeluaran perusahaan yang diakibatkan oleh rusaknya fasilitas produksi. Salah satunya adalah kerusakan mesin. Mesin merupakan sarana penting dalam suatu proses produksi dalam perusahaan. Mesin yang rusak secara mendadak dapat mengganggu rencana produksi yang telah ditetapkan. Untuk menanggulangi hal tersebut diperlukan perencanaan perawatan mesin yang terjadwal (preventive maintenance) untuk mengurangi kerusakan mesin mendadak (failure maintenance).

PT. PRIMA MITRA KARSA merupakan perusahaan yang terletak di Jl. Raya Pandan Landung no.88, barang yang memproduksi buku tulis, buku gambar, dan note. Mesin produksi yang mereka gunakan yaitu mesin shrink, mesin stitching, mesin sering. Kerusakan yang paling sering terjadi yaitu pada mesin stitching yang mengakibatkan proses produksi berhenti untuk dilakukan perbaikan mesin. Perawatan dilakukan saat mesin mengalami kerusakan secara tiba-tiba, sehingga akan menimbulkan kerugian bagi perusahaan yaitu berupa kehilangan produk yang seharusnya dihasilkan selama proses produksi atau kerugian penjualan (loss sale). Untuk menyelesaikan permasalahan tersebut, dibutuhkan adanya perencanaan perawatan stitching machine dengan menggunakan metode Reliability Centered Maintenance (RCM). RCM merupakan metode perawatan yang memanfaatkan informasi yang berkenaan dengan keandalan suatu fasilitas, untuk memperoleh strategi perawatan yang efektif. Sehingga diharapkan biaya penggantian komponen mesin menjadi minimum[1].

Menurut Kurniawan (2013) [2] Reliability Centered Maintenance (RCM) merupakan suatu metode perawatan yang memanfaatkan informasi yang berkenan dengan keandalan suatu fasilitas, untuk memperoleh strategi perawatan yang efektif, efisien dan mudah untuk dilakukan. Melalui penggunaaan RCM, dapat diperoleh informasi apa saja yang harus dilakukan untuk menjamin mesin/peralatan dapat terus beroperasi dengan baik. RCM merupakan suatu teknik yang dipakai untuk mengembangkan Preventive maintenance[3]. Hal ini didasarkan pada prinsip bahwa keandalan dari peralatan dan stuktur dari kinerja yang akan dicapai adalah fungsi dari perencanaan dan kualitas pembentukan preventive maintenance yang efektif[4]. Perencanaan tersebut juga meliputi komponen pengganti yang telah diprediksikan dan direkomendasikan[5]. Adapun tujuan dari penelitian ini adalah : 1) Mengetahui komponen mesin yang paling kritis dari mesin pendukung sistem mesin stitching, 2) Mendapatkan sistem perawatan yang efektif dan efisien dengan menggunakan motode Reliability Centered Maintenance (RCM), 3) Menentukan interval waktu penggantian dari komponen mesin kritis dengan Total Minimum Downtime (TMD).

\section{Metode Penelitian}

Objek makalah ini fokus pada mesin stitching PT. Prima Mitra Karsa, karena untuk stitching memiliki tingkat kerusakan yang tinggi, downtime produksi, dan komponen kritis. Data pada makalah ini adalah data downtime, breakdown, komponen kritis dan data lama perbaikan komponen mesin stitching. 
Tahapan pengolahan data dilakukan dengan pemilihan sistem dan pengumpulan informasi, definisi batasan sistem, deskripsi sistem dan Functional Block Diagram, penentuan fungsi sistem dan kegagalan fungsional, Failure Mode Effect Analysis (FMEA), Logic Tree Analysis (LTA), Pemilihan Tindakan, penentuan pola distribusi, penentuan Total Minimum Downtime.

Tahapan pengerjaan dengan metode Reliability Centered Maintenance :

a. Pemilihan hierarki fungsi sistem peralatan

Tujuan dari tahapan ini adalah untuk mengetahui fungsi masing-masing part atau komponen dari mesin stitching.

b. Definisi batasan sistem

Batasan sistem mengenai masukan (input) dan keluaran (output) dari suatu system diperlukan untuk mengetahui apakah antar part atau komponen saling berhubungan dalam suatu fungsi sistem.

c. Deskripsi sistem dan Functional Block Diagram

Langkah pendeskripsian sistem diperlukan untuk mengetahui komponen-komponen yang terdapat di dalam sistem dan bagaimana komponen komponen yang terdapat dalam sistem tersebut beroperasi. Sedangkan informasi fungsi peralatan dan cara sistem beroperasinya dipakai sebagai informasi untuk membuat dasar untuk menentukan kegiatan perawatan terencana untuk membuat Functional Block Diagram.

d. Menentukan fungsi sistem dan kegagalan fungsional

Setelah diperoleh deskripsi sistem, dilakukan tahapan analisis mengenai kegagalan fungsi yang terjadi pada mesin stitching.

e. Perhitungan Failure Mode and Effect Analysis (FMEA)

Analisa kegagalan dilakukan dengan lebih menekankan pada analisa kualitatif dan mengidentifikasikan dampak mode kegagalan dari komponen yang terdapat pada mesin stitching dengan menggunakan Failure Mode and Effect Analysis (FMEA).

f. Menentukan Logic Tree Analysis (LTA)

Analisis LTA dilakukan untuk memberikan prioritas mode kerusakan melakukan tinjauan dan fungsi, kegagalan fungsi sehingga status mode kerusakan tidak sama. Prioritas suatu mode kerusakan dapat diketahui dengan menjawab pertanyaanpertanyaan yang disediakan dalam LTA .

g. Menentukan pemilihan tindakan

Tahap pemilihan tindakan (Task Selection) merupakan tahap terakhir dalam proses RCM untuk menentukan tindakan yang paling mungkin diterapkan dan efektif untuk setiap mode kegagalan komponen yang terdapat pada mesin stitching.

h. Penentuan pola distribusi

Pada tahap ini dilakukan pemilihan pola distribusi dengan menggunakan waktu antar kerusakan pada mesin stitching, dengan menggunakan software Easy Fit.

i. Penetuan Total Minimum Downtime

Setelah uji pola distribusi menentukan iterval perawatan mesin yang optimum yang didapatkan dari pemilihan hasil yang paling minimum untuk mengurangi waktu downtime dan mendapatkan jadwal perawatan pada komponen mesin stitching.

\section{Hasil dan Pembahasan}

\subsection{Pembuatan Hierarki Fungsi Sistem Peralatan}

Menurut Rasyindo (2015) [6] proses identifikasi fungsi dari masing-masing sistem dan sub sistem perlu dilakukan untuk menentukan hierarki fungsional dari suatu sistem maupun sub sistem, sehingga dapat menunjukan fungsi utama mana saja 
yang mungkin tidak beoperasi jika fungsi tertentu mengalami kegagalan. Sistem ini dilakukan pada sistem produksi buku pada mesin stitching yang terdiri dari beberapa subsistem, yaitu: Mata pisau, V-belt, kumparan, Pegas, Bearing, Motor penggerak.

\subsection{Pendefinisian Batasan Sistem}

Menurut Rasyindo (2015) [6] batasan sistem merupakan suatu definisi kasar mengenai sistem dan batasan yang telah ditetapkan. Batasan sistem sangat diperlukan untuk mengetahui apa yang menjadi masukan (input) dan keluaran (output) dari suatu sistem. Batasan sistem pada mesin stitching terdapat pada tabel 1.

Tabel 1 Batasan Sistem

\begin{tabular}{|c|c|c|c|}
\hline \multirow{2}{*}{ Subsistem } & \multirow{2}{*}{ Komponen } & \multicolumn{2}{|c|}{ Batasan fisik primer } \\
\hline & & Start with & Terminate with \\
\hline \multirow[t]{2}{*}{$\begin{array}{c}\text { Power } \\
\text { transmition }\end{array}$} & $\begin{array}{c}\text { Motor penggerak } \\
\text { Van belt }\end{array}$ & $\begin{array}{l}\text { Tranmisi daya motor } \\
\text { penggerak } \\
\text { ditranmisikan } \\
\text { dengan }\end{array}$ & \multirow[t]{2}{*}{$\begin{array}{l}\text { Hasil transmisi motor } \\
\text { penggerak akan } \\
\text { menggerakkan poros as }\end{array}$} \\
\hline & Bearing & $\begin{array}{l}\text { menggunakan van } \\
\text { belt }\end{array}$ & \\
\hline \multirow{3}{*}{$\begin{array}{l}\text { Kepala } \\
\text { mesin }\end{array}$} & Kumparan & \multirow{3}{*}{$\begin{array}{l}\text { Pengoperasian oleh } \\
\text { operator }\end{array}$} & Pegas \\
\hline & Pegas & & $\begin{array}{lll}\text { mengembalikan posisi } \\
\text { semula mata pisau }\end{array}$ \\
\hline & Mata pisau & & $\begin{array}{lr}\text { setelah } & \text { operator } \\
\text { melakukan } & \text { penjahitan } \\
\text { pada buku } & \end{array}$ \\
\hline
\end{tabular}

\subsection{Deskripsi Sistem dan Diagram Blok Fungsi}

Menurut Rasyindo [6] fungsi sistem digunakan untuk mengidentifikasi desain sistem yang kritis, hubungan antar komponen dan pengaruhnya terhadap kinerja sistem. Informasi yang ada digunakan untuk membuat fuctional block diagram untuk mengentifikasi sistem dengan rinci. Adapun tahapan identifikasi detail dari sistem, yaitu : 1) Diskripsi Sistem. 2) Blok Diagram.

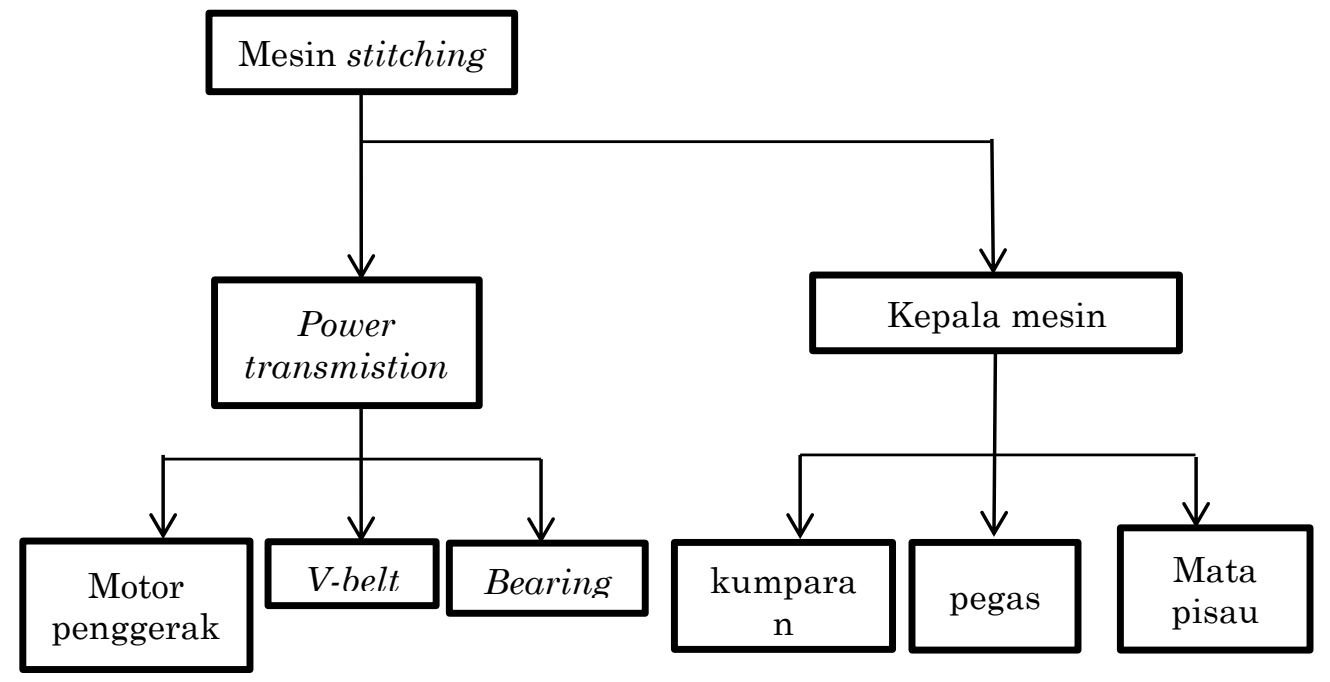

Gambar 1 Functional Block Diagram Mesin stitching 


\subsection{Fungsi Sistem dan Kegagalan Fungsi}

Menurut Rasyindo (2015) [6] fungsi sistem dan kegagalan fungsional dapat diketahui berdasarkan deskripsi sistem, informasi kerusakan yang terjadi, dan pengamatan secara langsung terhadap sistem yang diteliti. Pada tahap ini, dilakukan analisis mengenai kegagalan fungional yang terjadi pada sistem yang diteliti, penjelasan mengenai kegagalan, komponen yang terkait serta hubungan antar komponen pada sistem tersebut. Pada tabel 2 dapat dilihat fungsi dan kegagalan fungsi pada mesin stitching.

Tabel 2 Fungsi sistem dan kegagalan fungsional

\begin{tabular}{|c|c|c|c|}
\hline No. & $\begin{array}{c}\text { Nama } \\
\text { komponen }\end{array}$ & Deskripsi fungsi & Kegagalan fungsi \\
\hline 1 & $\begin{array}{c}\text { Motor } \\
\text { penggerak }\end{array}$ & $\begin{array}{l}\text { Pengubah dari listrik ke gerak } \\
\text { untuk menggerakan poros as. }\end{array}$ & $\begin{array}{c}\text { Poros as tidak dapat } \\
\text { berputar }\end{array}$ \\
\hline 2 & Bearing & Menopang pully & $\begin{array}{c}\text { Pully tidak dapat berputar } \\
\text { dengan baik }\end{array}$ \\
\hline 3 & $V$-belt & $\begin{array}{l}\text { Menghubungkan antara daya poros } \\
\text { yang satu dengan poros yang lain }\end{array}$ & $\begin{array}{l}\text { Kedua poros tidak saling } \\
\text { terhubung }\end{array}$ \\
\hline 4 & Kumparan & $\begin{array}{c}\text { Untuk melilitkan dan memutar } \\
\text { kawat }\end{array}$ & $\begin{array}{l}\text { kawat tidak dapat } \\
\text { berputar }\end{array}$ \\
\hline 5 & Pegas & $\begin{array}{l}\text { Mengembalikan mata pisau ke } \\
\text { posisi semula }\end{array}$ & $\begin{array}{l}\text { Mata pisau tidak dapat } \\
\text { kembali ke posisi semula }\end{array}$ \\
\hline 6 & Mata pisau & Memotong kawat & $\begin{array}{l}\text { Kawat tidak dapat } \\
\text { terpotong }\end{array}$ \\
\hline
\end{tabular}

\subsection{Failure Mode and Effect Analysis (FMEA)}

Menurut Rasyindo (2015) [6] mode kegagalan merupakan suatu keadaan yang dapat menyebabkan kegagalan fungsional. Sehinggga apabila mode kegagalan dapat diketahui maka dampak kegagalan dari suatu sistem dapat digambarkan. Mode kegagalan dapat digunakan untuk menentukan konsekuensi dan memutuskan apa yang akan dilakukan untuk mengantisipasi, mencegah, mendeteksi, dan memperbaiki. Berdasarkan dari analisa failure mode and effect analysis (FMEA) pada komponen mesin stitching dapat diperoleh nilai RPN (Risk Priority Number) untuk setiap komponen sehingga dapat di berikan perhatian yang lebih terhadap komponen yang mempunyai nilai RPN paling besar[7], yaitu dengan menerapkan tindakan yang tepat. Nila RPN dapat dilihat pada tabel 3.

Tabel 3 RPN kegagalan komponen mesin stitching

\begin{tabular}{ccccc}
\hline Komponen & S & O & D & RPN \\
\hline Bearing & 7 & 5 & 6 & 210 \\
V-belt & 8 & 6 & 4 & 192 \\
Pegas & 6 & 5 & 5 & 150 \\
Mata pisau & 8 & 6 & 2 & 96 \\
Kumparan & 6 & 4 & 3 & 72 \\
Motor penggerak & 10 & 2 & 2 & 40 \\
\hline
\end{tabular}




\subsection{Logic Tree Analysis (LTA)}

Menurut Hakim (2014) [8] penyusunan LTA merupakan proses kualitatif, tujuan tahap ini adalah memberikan prioritas pada tiap mode kerusakan dan melakukan tinjauan dari fungsi, sehingga status mode kerusakan pada kegagalan fungsi tidak sama. Proses LTA menggunakan pertanyaan logika yang sederhana atau struktur keputusan kedalam empat kategori, setiap pertanyaan akan dijawab "Ya" atau "Tidak"[9]. Berdasarkan hasil dari penentuan Logic Tree Analysis (LTA).Maka dapat diperoleh kategori kegagalan dari masing-masing komponen mesin. Adapun pengkategorian pada masing-masing komponen tersebut dilakukan pertimbangan sebagai berikut:

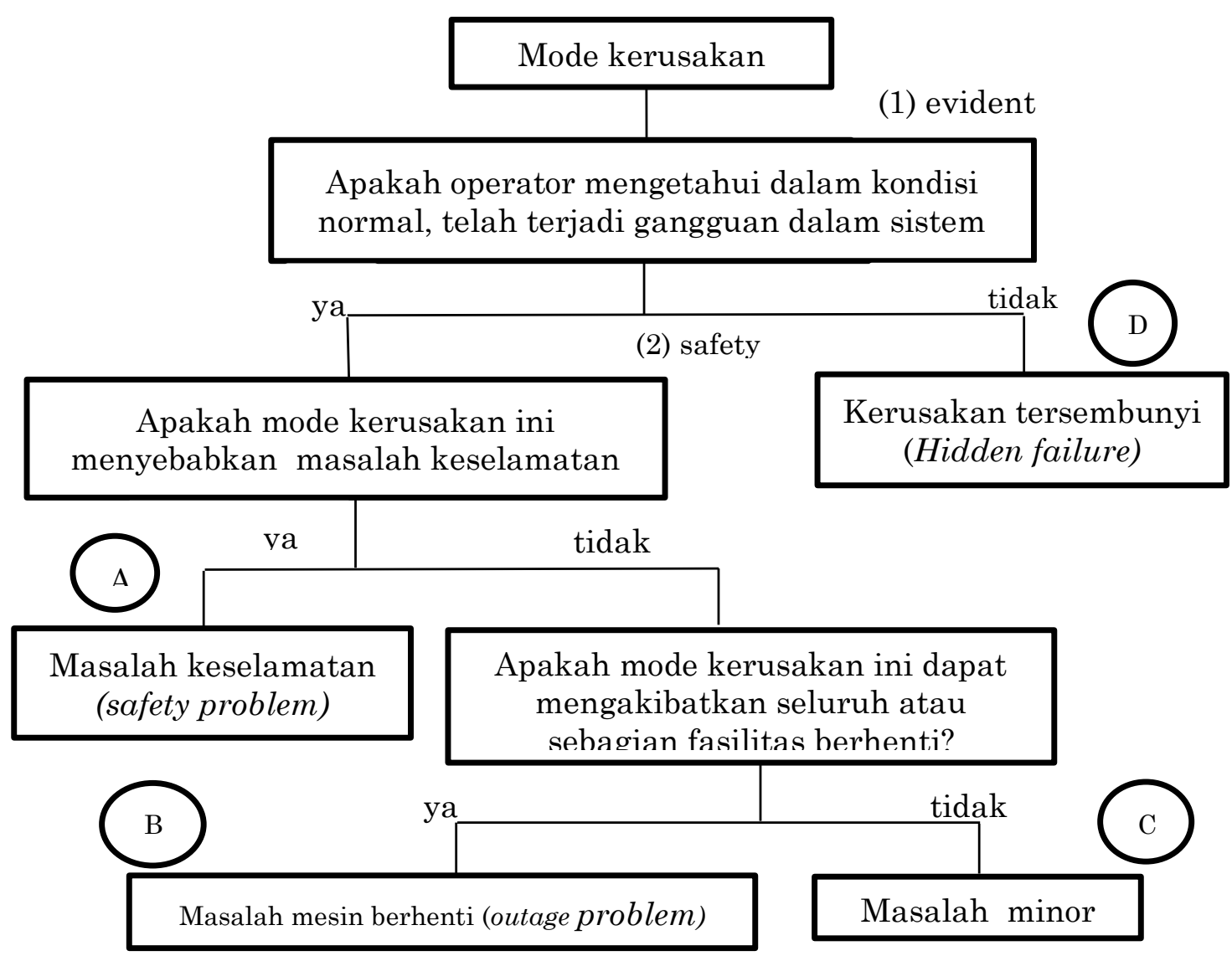

Gambar 2 Struktur Logic tree analisys

1. Kategori A (safety problem) yaitu komponen yang dapat mengakibatkan gangguan keselamatan pada operator dan lingkungan. Berdasarkan hasil penelitian, tidak ada komponen yang termasuk dalam kategori ini.

2. Kategori B (outage problem) yaitu komponen yang dapat mengakibatkan kegagalan pada seluruh atau sebagian sistem. Adapun komponen yang termasuk dalam kategori ini adalah:
a. kumparan
b. Bearing
c. pegas
d. Mata pisau
e. V-belt 


\subsection{Pemilihan Tindakan}

Menurut Hakim (2014) [8] pemilihan tindakan merupakan tahap terakhir dari proses analisa RCM. Dari tiap mode kerusakan dibuat daftar tindakan yang mungkin untuk dilakukan dan selanjutnya memilih tindakan yang efektif. Adapun pemilihan tindakan untuk setiap komponen ditentukan dalam tindakan time directed dan condition directed. Diagram alir pemilihan tindakan dan berdasarkan analisis terhadap FMEA dan LTA, juga dilihat tingkat kerusakan yang sering dari data yang ada serta tingkat ekonomi yang bisa merugikan perusahaan[4, 10]. Pemilihan tindakan untuk komponen kritis mesin stitching adalah sebagai berikut :

1. Condition Directed (CD)

Bertujuan untuk mendeteksi kerusakan dengan cara memeriksa alat, serta memonitoring sejumlah data yang ada. Apabila ada pendeteksian ditemukan gejalagejala kerusakan peralatan maka dilanjutkan dengan perbaikan atau penggantian komponen. Komponen yang termasuk dalam pemilihan tindakan ini adalah:

a. Pegas

b. Mata pisau

c. Kumparan

2. Time Directed (TD)

Time Directed lebih berfokus pada aktivitas pergantian yang dilakukan secara berkala dengan berdasarkan perhitungan reliability.

a. V-belt

b. Bearing

\subsection{Uji Pola Distribusi dengan Software Easyfit 5.6}

Berdasarkan hasil analisis RCM pada mesin stitching, maka perhitungan reliability dilakukan pada komponen yang termasuk dalam pemilihan tindakan Time Directed (TD). Komponen-komponen tersebut yaitu V-belt dan Bearing.

Interval kerusakan komponen diuji menggunakan 5 pola distribusi, yaitu distribusi weibull, normal, lognormal, exponensial dan gamma (distribusi yang umum digunakan dalam reliability). Untuk pengujian pola distribusi dalam reliability ini, menggunakan software Easy Fit Professional 5.6. Dengan menggunakan kolmogrov smirnov sebagai goodness of fit, dapat ditentukan kecenderungan data kerusakan untuk mengikuti pola distribusi dalam reliability, dan distribusi data yang teramati khususnya untuk jumlah data yang tidak terlalu besar (dibawah 30). Hasil uji distribusi untuk masing-masing komponen menggunakan software Easy Fit Standart 5.6 selengkapnya dapat dilihat pada lampiran. Hasil rekapitulasi uji distribusi dan parameternya dapat dilihat pada Tabel 4.

Tabel 4 Rekapitulasi Uji Distribusi Dan Penentuan Parameter Interval Kerusakan

\begin{tabular}{cccc}
\hline No & Komponen & Pola Distribusi & Parameter \\
\hline 1 & V-Belt & Normal & $\alpha=22,345 ; \beta=58,6$ \\
2 & Bearing & Normal & $\alpha=7,2595 ; \beta=57,8$ \\
\hline
\end{tabular}

\subsection{Perhitungan Total Minimum Downtime}

Berdasarkan data parameter tabel 3. maka dapat ditentukan total minimum downtime pada masing-masing komponen. Lama perbaikan komponen kritis dengan $\mathrm{T}_{\mathrm{f}}$ adalah waktu yang diperlukan untuk mengganti komponen karena komponen mengalami kerusakan dan $\mathrm{T}_{\mathrm{p}}$ adalah waktu yang diperlukan untuk pergantian 
komponen tindakan preventif. Adapun untuk mendapatkan downtime yang minimum maka harus melalui beberapa tahapan. Tabel 5 merupakan hasil perhitungan Total Minimum Downtime.

Tabel 5 Perhitungan Total Minimum Downtime (TMD)

\begin{tabular}{ccc}
\hline No. & Komponen & Interval Pergantian Optimum \\
\hline 1 & V-belt & Pergantian komponen dilakukan setiap 21 hari \\
2 & Bearing & Pergantian komponen dilakukan setiap 47 hari \\
\hline
\end{tabular}

Tabel 6 Penurunan Downtime Sistem Perawatan Sekarang dan Usulan

\begin{tabular}{|c|c|c|c|c|c|c|}
\hline \multirow[b]{2}{*}{ No } & \multirow[b]{2}{*}{ Komponen } & \multicolumn{2}{|c|}{$\begin{array}{c}\text { Sistem Perawatan } \\
\text { Sekarang }\end{array}$} & \multicolumn{2}{|c|}{$\begin{array}{c}\text { Sistem Perawatan } \\
\text { Usulan }\end{array}$} & \multirow[b]{2}{*}{$\begin{array}{c}\text { Penurunan } \\
\text { Downtime } \\
(\%)\end{array}$} \\
\hline & & $\begin{array}{c}\text { Interval } \\
\text { Pergantian } \\
\text { Komponen } \\
\text { (Hari) }\end{array}$ & Downtime & $\begin{array}{c}\text { Interval } \\
\text { Pergantian } \\
\text { Komponen } \\
\text { (Hari) }\end{array}$ & Downtime & \\
\hline 1 & $V$-Belt & 59 & 0,009085 & 21 & 0,002480 & $72,70 \%$ \\
\hline 2 & Bearing & 58 & 0,001820 & 47 & 0,001402 & $22,96 \%$ \\
\hline \multicolumn{6}{|c|}{ Total penurunan downtime rata-rata } & $47,83 \%$ \\
\hline
\end{tabular}

Berdasarkan hasil pendekatan RCM, maka waktu downtime mesin dapat diminimumkan. Tabel 6. menunjukkan adanya penurunan downtime sebesar $47,83 \%$

\section{Simpulan}

Dalam makalah dan perencanaan tindakan perawatan mesin stitching di PT. Prima mitra karsa Malang, jawa Timur ini didapatkan kesimpulan sebagai berikut: komponen yang memiliki Risk Priority Number (RPN) terbesar yaitu Bearing 210, V-belt 192, Pegas 150 sehingga membutuhkan perawatan yang lebih. Hasil pemilihan tindakan perawatan RCM terdapat 3 komponen yang yang direncanakan dengan perawatan CD (Condition Directed), yaitu kumparan, pegas, mata pisau dan 2 komponen yang direncanakan dengan perawatan TD (Time Directed) yaitu V-belt dan Bearing. Interval penggantian optimum komponen dengan Total Minimum Downtime yaitu V-belt sebesar 21 hari dan Bearing 47 hari. Dengan mengusulkan metode RCM sebagai metode perawatan, maka dapat dilihat adanya potensi penurunan rata-rata downtime sebesar $47,83 \%$.

\section{Referensi}

[1] J. Heo, M. Kim, and J. Lyu, "Implementation of reliability-centered maintenance for transmission components using particle swarm optimization," International Journal of Electrical Power \& Energy Systems, vol. 55, pp. 238-245, 2014.

[2] F. Kurniawan, "Manajemen perawatan industri," Yogyakarta. Graha Ilmu, 2013.

[3] P. Chemweno, L. Pintelon, A. Van Horenbeek, and P. Muchiri, "Development of a risk assessment selection methodology for asset maintenance decision making: An analytic network process (ANP) approach," International Journal of Production Economics, vol. 170, pp. 663-676, 2015. 
[4] H. J. Groenewald, M. Kleingeld, and J. Vosloo, "A performance-centred maintenance strategy for industrial DSM projects," in Industrial and Commercial Use of Energy (ICUE), 2015 International Conference on the, 2015, pp. 50-53.

[5] B. Yssaad, M. Khiat, and A. Chaker, "Reliability centered maintenance optimization for power distribution systems," International Journal of Electrical Power \& Energy Systems, vol. 55, pp. 108-115, 2014.

[6] M. R. Rasindyo, K. Leksananto, and Y. Helianty, "Analisis Kebijakan Perawatan Mesin Cincinnati Dengan Menggunakan Metode Reliability Centered Maintenance Di Pt. Dirgantara Indonesia," REKA INTEGRA, vol. 3, 2015.

[7] W. Hayes, J. Cohen, and R. Ferguson, "Risk Priority Number: A Method for Defect Report Analysis," Carnegie-Mellon Univ Pittsburgh Pa Software Engineering INST2014.

[8] L. Hakim, "Penerapan Rcm Pada Sistem Distribusi Air Di Pdam Pasir Putih Pematangan Barangan Kabupaten Rokan HulU," Jurnal APTEK, vol. 4, pp. 129140, 2014.

[9] W. Marzocchi, M. Taroni, and J. Selva, "Accounting for epistemic uncertainty in PSHA: Logic tree and ensemble modeling," Bulletin of the Seismological Society of America, vol. 105, pp. 2151-2159, 2015.

[10] T. Annaka, K. Satake, T. Sakakiyama, K. Yanagisawa, and N. Shuto, "Logic-tree approach for probabilistic tsunami hazard analysis and its applications to the Japanese coasts," in Tsunami and Its Hazards in the Indian and Pacific Oceans, ed: Springer, 2007, pp. 577-592. 